\title{
The course of digestion of different food proteins in the rat
}

\section{3.* The absorption of proteins given alone and with supplements of their limiting amino acids}

\author{
By B. A. ROLLS, J. W. G. PORTER AND D. R. WESTGARTH \\ National Institute for Research in Dairying, Shinfield, Reading $R G 29 A T$
}

(Received 27 August 197I - Accepted 20 April I972)

\begin{abstract}
r. Single meals of casein, $\alpha$-protein, a commercial soya-bean assay protein, wheat gluten and zein $\left(24^{*} 3 \mathrm{mg}\right.$ nitrogen/ I oo $\mathrm{g}$ body-weight) were given with and without supplements of their limiting amino acids to groups of rats housed in anti-coprophagy cages, after an $8 \mathrm{~h}$ fast. At intervals after feeding, rats were anaesthetized, samples of portal and cardiac blood were taken for the determination of free amino acid concentrations in deproteinized plasma (PAA concentrations), and the contents of the gastro-intestinal tract were collected and analysed.

2. The different proteins left the stomach at different rates and gave different concentrations of nitrogen and dry matter in the small intestine contents. Supplementary amino acids caused no alteration in the total rate of passage, digestion or absorption.

3. The supplementary amino acids were gencrally absorbed more rapidly than amino acids derived from the protein.

4. It was not possible to use the changes in PAA concentrations as criteria to detect enhanced utilization of proteins resulting from the addition of amino acids. A fall in PAA concentrations upon adding these supplements, indicating increased protein synthesis, was demonstrated for only one test protein, gluten.
\end{abstract}

With greater commercial availability of synthetic amino acids it has become a matter of increasing economic and nutritional concern whether free amino acids are efficiently utilized when given as dietary supplements with intact proteins. Amino acids must be available simultaneously at the sites of synthesis for maximum utilization (Melnick, Oser \& Weiss, 1946) and free amino acid supplements are relatively ineffective when given at different times from the main diet (e.g. Berg \& Rose, 1929; Geiger, 1947). Indeed, such supplementation of food proteins has been criticized on the grounds that the rates of absorption of free amino acids and of those liberated from the protein may be dissimilar. Longenecker \& Hause (1958) showed that, with dogs, free amino acid supplements were absorbed at a rate sufficiently similar to those of the amino acids from the readily digested proteins, gluten and gelatin, to ensure sufficient utilization.

The main aims of the work reported here were: to examine in the rat the effects of supplementation of a range of food proteins of different solubility and nutritive value to determine whether supplementation affects the time-course of digestion; to investigate whether changes in blood amino acid concentrations during the $3 \mathrm{~h}$ postprandial period may be used to detect increased tissue protein synthesis. A preliminary report of some earlier findings has been made (Rolls, Williams \& Porter, 1969).

* Paper no. 2: Br. F. Nutr. (1971), 25, 299. 


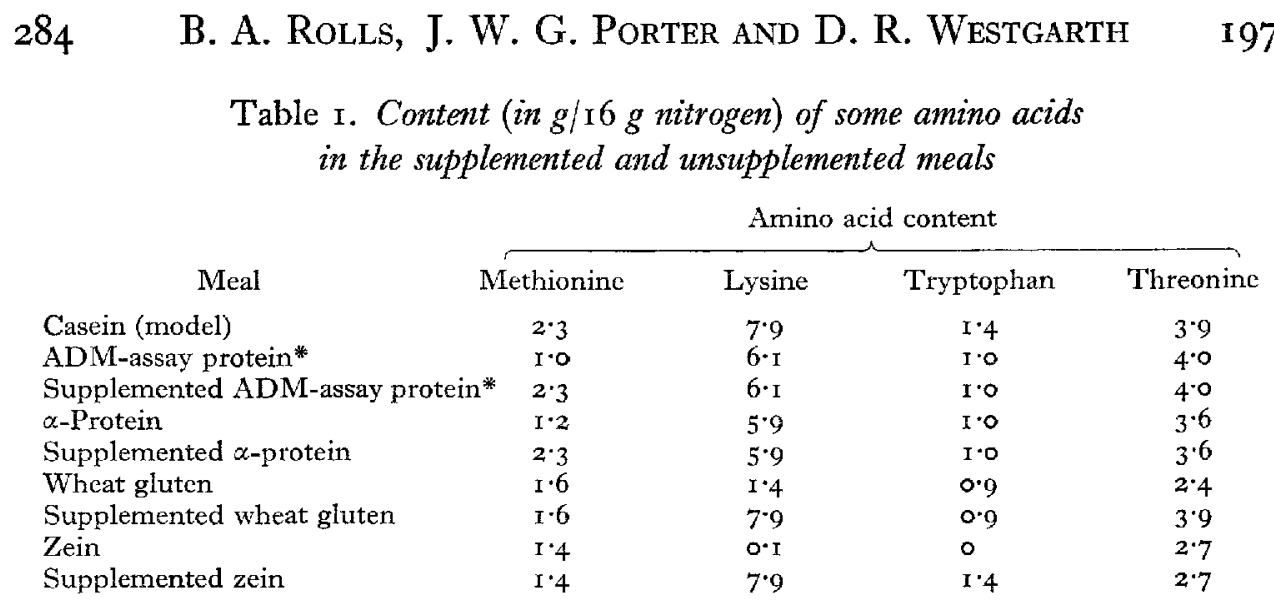

* Obtained from Archer Daniels Midland Co., Minneapolis, USA.

\section{EXPERIMENTAL}

Diets

A soya-bean assay protein (Archer Daniels Midland Co., Minneapolis, USA) (ADM-assay protein), $\alpha$-protein, zein and wheat gluten were given, alone and supplemented with the first, or the first and second, limiting amino acids. Supplements were: to ADM-assay protein and $\alpha$-protein - methionine; to zein-lysine and tryptophan; and to wheat giuten-lysine and threonine. Casein was selected as the model to which the other proteins were to be matched; for example L-lysine and L-tryptophan were added to zein in amounts such that the total levels of these amino acids in supplemented zein were the same as those in cascin, i.e. $7 \cdot 9$ and $\mathrm{r} \cdot 4 \mathrm{~g} / \mathrm{I} 6 \mathrm{~g}$ nitrogen respectively (see Table $\mathrm{r}$ ). Hence the isonitrogenous meals of casein and supplemented zein contained the same levels of lysine and tryptophan, wholly protein-bound in one, partly or wholly free in the other. In this way the effects of supplementation could be investigated and at the same time the absorption of free and of protein-bound amino acids could be compared. Casein itself was supplemented in a separate experiment with $0.5 \%$ methionine.

Wheat gluten and the L-amino acids were obtained from British Drug Houses Ltd, Poole, Dorset; zein from Corn Products (Sales) Ltd, Manchester. The sources of the other proteins have been given in previous papers in the series (Zebrowska, 1968; Buraczewski, Porter, Rolls \& Zebrowska, I971).

\section{Tests with rats}

The experimental procedure for the tests with rats was as described by Buraczewsiki et al. (1971): all the meals were given in amounts calculated to supply $14 \cdot 3 \mathrm{mg} \mathrm{N} /$ Ioo g body-weight to groups of six or more rats kept in anti-coprophagy cages after an I $8 \mathrm{~h}$ fast; plasma free amino acid concentrations in deproteinized portal and cardiac blood plasma (PAA concentrations) were determined at various times after feeding. The accuracy of estimation of threonine and serine in plasma was reduced by the presence of glutamine and asparagine peaks and, since the threonine concentration in certain samples was of particular interest, a portion of these samples was hydrolysed with 
constant-boiling $\mathrm{HCl}$ to destroy the amides. The hydrolysate was then evaporated to dryness and dissolved in citrate buffer of $\mathrm{pH}_{2 \cdot 2}$ for application to the analyser column.

$\mathrm{N}$ and dry-matter concentrations in the contents of the gastro-intestinal tract were determined, and pooled soluble contents of the stomachs and of the small intestines from six or more rats were fractionated on Sephadex $\mathrm{G}-25$ and ninhydrin profiles of the $\alpha$-amino $\mathrm{N}$ were calculated. Those fractions containing protein, peptide or free amino acids were identified by comparison with runs using compounds of known molecular weight (Zebrowska, I968). The fractions were concentrated under reduced pressure and were hydrolysed with constant-boiling $\mathrm{HCl}$. The amino acid composition of each fraction was then determined after evaporation of the hydrolysate and re-solution in $\mathrm{pH} 2 \cdot 2$ citrate buffer.

\section{RESULTS}

\section{Gastro-intestinal contents}

The $\mathrm{N}$ and dry-matter contents in the stomach and in the small intestine after feeding with supplemented and unsupplemented proteins are given in Table 2; the contents after an $\mathrm{i} 8 \mathrm{~h}$ fast are shown for comparison. These results show that the extent of stomach emptying depended greatly on the protein given, as was found under different conditions by Geiger (I95I) and Gupta, Dakroury \& Harper (I958). About one-quarter of the meal remained in the stomach $2 \mathrm{~h}$ after casein, zein or ADM-assay protein had been given. Gluten was very soluble in the stomach, whereas zein was so insoluble that the concentration of dissolved $\mathrm{N}$ after $2 \mathrm{~h}$ was not raised above the fasting value.

The amounts of the soluble nitrogenous compounds in the small intestine were about twice the fasting value at $2 \mathrm{~h}$ after giving casein, ADM-assay protein and zein. Higher values were recorded for gluten, which readily passed into solution in the stomach, and for $\alpha$-protein, which disappeared from the gut more slowly than the other proteins of similar solubility tested during the first $2 \mathrm{~h}$ after feeding. Zein was insoluble in the small intestine, as in the stomach, and was the only protein of those used with which considerably more insoluble $\mathrm{N}$ was found than in fasted animals.

Despite these variations when different proteins were given, supplementing with amino acids caused little change in the pattern of digestion of individual proteins; those differences which were found were not consistent. Small amounts of free amino acids given as supplements had no consistent effect on the rate of stomach emptying (cf. Rogers, Spolter \& Harper, I962), even though large meals of free amino acids, despite their solubility, left the stomach relatively slowly (Buraczewski, Porter, Rolls and Zebrowska, unpublished).

The concentrations of $\alpha$-amino $\mathrm{N}$ in the soluble contents of the stomach and of the small intestine as protein, peptide and amino acids were calculated from the ninhydrin profiles, and those for the unsupplemented proteins are given in Table 3 . The values for the supplemented protein were similar in every instance to those for the corresponding unsupplemented protein. The soluble contents of the stomach consisted very largely of dissolved protein and larger peptides, the concentrations of free amino acids being relatively very low. The proportion of peptide depended on the 


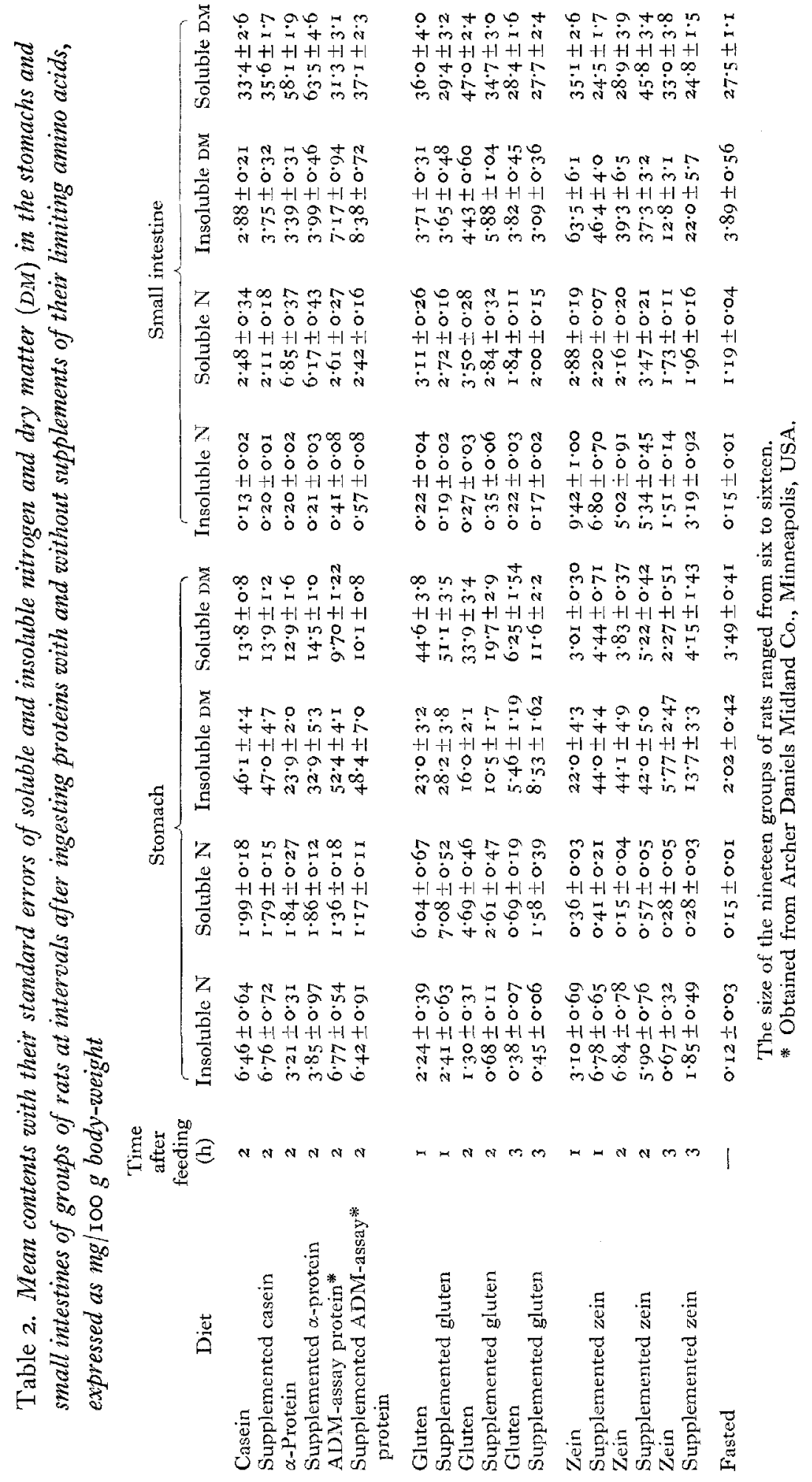


Table 3. Amount of 'proteins', 'peptides' and 'free amino acids' (expressed as mg leucine equivalent per $100 \mathrm{~g}$ body-zoight) in the soluble nitrogen fraction of the pooled contents of the stomachs, and of the small intestines, of groups of at least six rats after ingesting proteins

\begin{tabular}{|c|c|c|c|c|}
\hline Dict & $\begin{array}{l}\text { Time after } \\
\text { feeding }(\mathrm{h})\end{array}$ & 'Proteins' & 'Peptides' & $\begin{array}{l}\text { 'Amino } \\
\text { acids' }\end{array}$ \\
\hline \multicolumn{5}{|c|}{ Stomach } \\
\hline Cascin & 2 & 5.56 & $5 * 76$ & $2 \cdot 12$ \\
\hline$\alpha-P$ rotein & 2 & $4 \cdot 60$ & $8 \cdot 72$ & $x \cdot 66$ \\
\hline ADM-assay protein* & 2 & $2 \cdot 32$ & $6 \cdot 48$ & $I \cdot 42$ \\
\hline Gluten & I & $29 \cdot 0$ & $8 \cdot 3$ & 44 \\
\hline Gluten & 2 & $2 I \cdot 8$ & $14 \cdot 7$ & $4^{*} 9$ \\
\hline Gluten & 3 & $I \cdot 90$ & $2 \cdot 94$ & 0.44 \\
\hline \multicolumn{5}{|c|}{ Small intestine } \\
\hline Fasted & - & 3.02 & 0.94 & $3 \cdot 44$ \\
\hline Casein & 2 & $3 \cdot 44$ & 3.08 & $7 \cdot 22$ \\
\hline$\alpha-$ Protein & 2 & $7 \cdot 80$ & $33 \cdot 12$ & $20 \cdot 76$ \\
\hline ADM-assay protein* & 2 & $4: 42$ & $4^{\prime 24}$ & $7 \cdot 58$ \\
\hline Gluten & I & $4 \cdot 86$ & 4.50 & $12 \cdot 20$ \\
\hline Gluten & 2 & $4 \cdot 62$ & $4 \cdot 84$ & $12 \cdot 64$ \\
\hline Gluten & 3 & $3 \cdot 18$ & $2 \cdot 70$ & $5 \cdot 90$ \\
\hline Zein & I & 3.66 & 6.06 & $13 \cdot 64$ \\
\hline Zein & 2 & $2 \cdot 64$ & $5 \cdot 12$ & $9 \cdot 48$ \\
\hline Zein & 3 & $2 \cdot 52$ & $3 \cdot 70$ & $7 \cdot 66$ \\
\hline
\end{tabular}

length of time the protein had spent in the stomach, as can be seen from the results for gluten, which show that the peptide:protein ratio increased with the length of time after feeding.

The composition of the soluble digesta in the small intestine differed more markedly with the different proteins given than did the stomach profiles. Since the proteins of the endogenous secretions are generally well digested, the results with fasted or carbohydrate-fed rats (Table 3 and Buraczewski et al. I97I) were predictably the same as those obtained when a readily digested exogenous protein such as casein was given, in that the concentrations of peptides found were low, compared with those of protein and free amino acids. However, giving less-well digested proteins, such as $\alpha$-protein, produced much higher concentrations of peptide, both in absolute quantity and in relation to the concentrations of free amino acids. The differences between the ninhydrin profiles after ingestion of the supplemented and unsupplemented meals were small. The absence of a rise in the free amino acid content of the stomach confirmed that the supplementary amino acids in the diet had left the stomach rapidly.

Buraczewski, Porter, Rolls and Zebrowska (unpublished) found that the amino acid composition of the soluble protein, peptide and free amino acid fractions was different when different proteins were given, and that these differences were related to the digestibility and composition of the diet. However, despite these possible variations, analysis of the amino acid content of the equivalent fractions from contents of the stomach and the small intestine after ingestion of supplemented and unsupplemented meals revealed no significant differences attributable to the addition of the free amino. acids. 
Table 4. Concentrations of amino acids in the portal and systemic plasma pools of six or more rats at intervals after ingesting proteins with and without supplements of limiting amino acids, expressed as $\mu \mathrm{mol} / \mathrm{1}$ oo $\mathrm{ml}$

\begin{tabular}{|c|c|c|c|c|c|}
\hline \multirow[b]{2}{*}{ Diet } & \multirow{2}{*}{$\begin{array}{l}\text { Time } \\
\text { after } \\
\text { feeding } \\
\text { (h) }\end{array}$} & \multicolumn{2}{|c|}{ Portal } & \multicolumn{2}{|c|}{ Systemic } \\
\hline & & Methionine & Lysine & Methionine & Lysine \\
\hline \multirow{3}{*}{ Casein (model) } & I & 157 & $84 \cdot 4$ & $8 \cdot 9$ & $56 \cdot 6$ \\
\hline & 2 & $15 \cdot 3$ & $90 \cdot 8$ & $7 \cdot 0$ & $54 \cdot 6$ \\
\hline & 3 & $10 \cdot 3$ & $66 \cdot 3$ & $6 * 9$ & $47 \cdot 2$ \\
\hline ADM-assay protein * & 2 & $1+9$ & $6 r \cdot 0$ & $4 \cdot 3$ & $56 \cdot 4$ \\
\hline Supplemented ADM-assay protein* & 2 & $12 \cdot 4 \uparrow$ & $63 \cdot 9$ & $8 \cdot 2 \dagger$ & $49 \cdot 1$ \\
\hline$\alpha$-Protein & 2 & $6 \cdot 5$ & $72 \cdot 2$ & $3 \cdot 5$ & 35.0 \\
\hline Supplemented $\alpha$-protein & 2 & $8 * 7 \dagger$ & $68 \cdot 3$ & $7 \cdot 2 \dagger$ & $47 \cdot 9$ \\
\hline Zein & I & $9 \cdot 6$ & $49^{\circ} 9$ & $7 \cdot 7$ & $48 \cdot 5$ \\
\hline Supplemented zein & I & $12 \cdot 1$ & $79 \cdot 1+$ & $10 \cdot 7$ & I $3.5 t$ \\
\hline Zein & 2 & $7 \cdot I$ & $4 I \cdot 3$ & $5 \cdot 9$ & $38 \cdot 2$ \\
\hline Supplemented zein & 2 & $7 \cdot 1$ & $62 \cdot 6 \dagger$ & $7 \cdot 8$ & $55 \cdot 2 \uparrow$ \\
\hline Zein & 3 & $6 \cdot I$ & $3^{8 \cdot 7}$ & $9 \cdot 5$ & $59^{\circ} 0$ \\
\hline Supplemented zein & 3 & $7 \cdot 9$ & $39 \cdot 7 \uparrow$ & 10.4 & $7 x \cdot 4 t$ \\
\hline Fasting & I & $5 \cdot 6$ & $40 \cdot 6$ & $5 \cdot 3$ & $48 \cdot 4$ \\
\hline
\end{tabular}

* Obtained from Archer Daniels Midland Co., Minneapolis, USA.

+ Supplemented with amino acid.

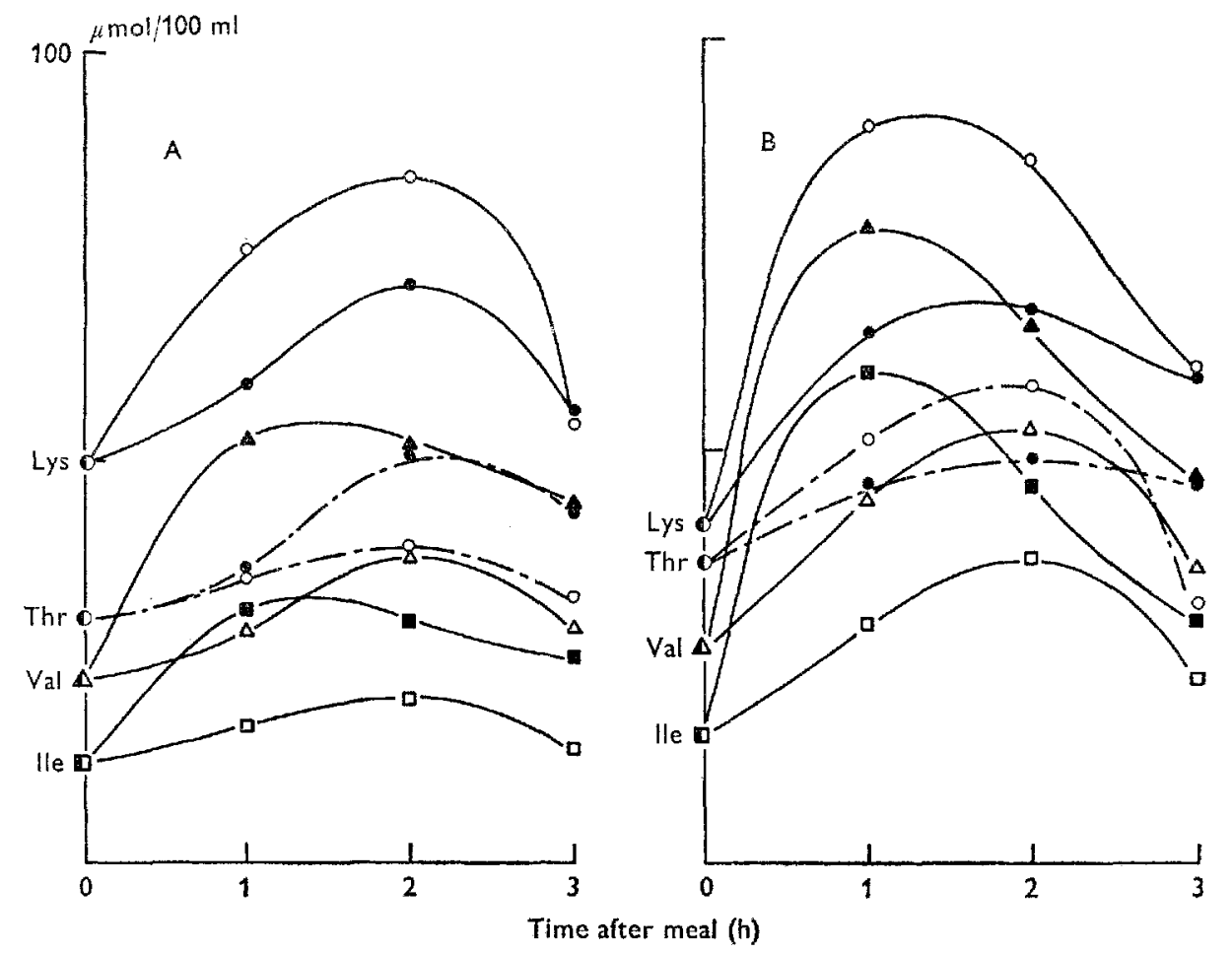

Fig. I. Variation of pooled (A) portal and (B) systemic plasma concentrations of lysine, threonine, valine and isoleucine with time after ingesting gluten (solid symbols) and gluten supplemented with lvsine and threonine (open symbols) in groups of rats. 
Table 5. Effects on plasma amino acid $(P A A)$ concentrations in the portal $(P)$ and systemic $(S)$ blood pools of groups of rats with time after ingestion of proteins unsupplemented or supplemented with their limiting amino acids

Let $x_{i}$ be the PAA concentration of the $i$ th amino acid after diet $x$, and let $y_{i}$ be the corresponding concentration after the supplemented diet $y$. The ratio $z_{i}=y_{i} \div x_{i}$ represents the relative effect of supplementation on the $i$ th amino acid. The mean relative effect is $\bar{z}=\Sigma z_{i} \div n$, where $n$ is the number of amino acids (excluding the supplementaries))

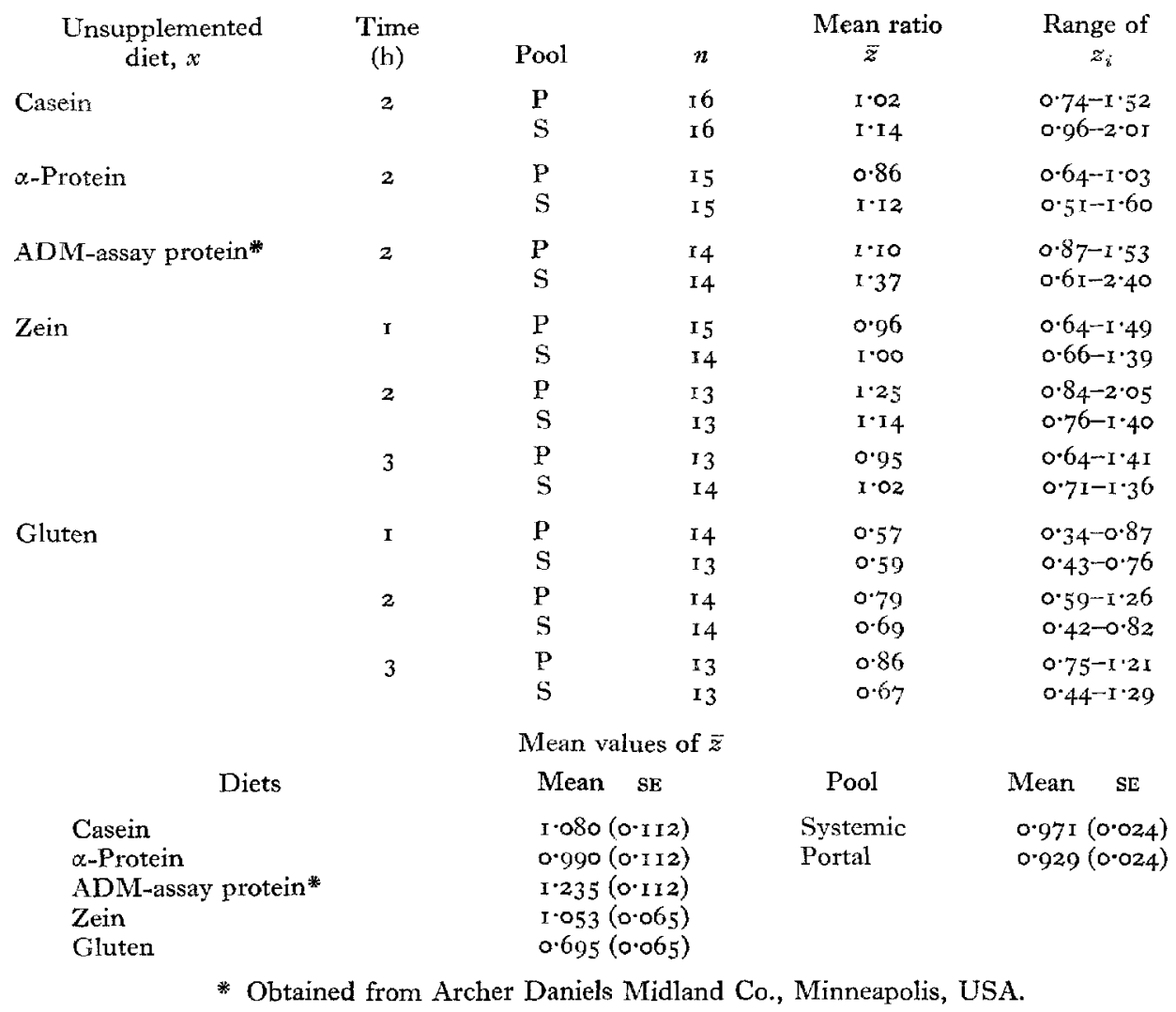

\section{$P A A$ concentrations}

In the experiments in which proteins were supplemented with methionine and in which zein was supplemented with lysine and tryptophan, the plasma concentrations of the supplementary amino acids were higher in both portal and systemic plasma at all sampling times when the supplemented meal was given than when the protein alone was ingested (Table 4). On the other hand, although the concentrations of lysine in the plasma when supplemented gluten was given were generally higher than when gluten alone was ingested, the rises were proportionately less, and often the threonine level fell (Fig. r).

The concomitant effects on the non-supplemented amino acids have been expressed by calculating the ratio, $z$, of the corresponding plasma amino acid concentrations after ingestion of the supplemented and of the unsupplemented meals. The smaller the 
change in concentration of an amino acid due to supplementation, the closer to unity will be the ratio $z$. The average effect on the non-supplementary amino acids is expressed as the arithmetic mean ratio $\bar{z}$ (Table 5 ). This demonstrates that when gluten was supplemented the mean ratio $\bar{z}$ was reduced significantly to 0.7 , whereas with the other proteins investigated no significant change was established.

\section{DISCUSSION}

It was concluded that the rate of stomach emptying, the passage of the digesta and the general course of digestion and absorption of the ingested protein were little affected by the addition of free amino acids at the levels used. Values for the stomach contents always displayed higher variability between individuals than did those for the intestinal contents, perhaps because gastric motility is susceptible to influences unrelated to the diet, such as the quantity of water drunk. The greater variation in the stomach contents of rats given gluten meals was attributed to the high solubility of this protein in the stomach juices.

When proteins were supplemented with methionine, its level in the supplemented meal was made equal to that in casein. If hydrolysis were not a rate-determining factor in the absorption of proteins the PAA concentrations would be independent of the form in which the amino acid was given. Thus the methionine concentrations after ingestion of casein are termed the 'expected' concentrations. However, it can be seen from Table 4 that at $2 \mathrm{~h}$ after giving $\alpha$-protein or $\mathrm{ADM}$-assay protein with methionine the concentration of this amino acid in portal blood lay between this expected concentration and that found on giving the protein alone. The corresponding systemic concentration was above the expected value. Since the concentrations of the amino acids other than methionine were the same after the ingestion of the supplemented and the unsupplemented meal, it is likely that the protein-bound portion of methionine in $\alpha$-protein and ADM-assay protein was absorbed at the same rate in the presence or absence of the free amino acid. The divergence of the observed from the expected concentrations of methionine after the supplemented meal had been given may be attributed to a different rate of absorption of the frce amino acid. The higher-than-expected concentration of methionine in systemic plasma implies that this rate was more rapid than for intact protein, whether the protein were $\alpha$-protein, ADM-assay protein or casein.

The same arguments may be applied to the plasma lysine concentrations after ingestion of zein and supplemented zein (Table 4). Comparison of these values after ingestion of supplemented zein shows that, at each sampling time, higher than expected systemic and lower than expected portal concentrations were found. In the portal plasma the lysine concentration after giving supplemented zein was closer to the expected level at $\mathrm{I} h$ after ingestion and closer to the level after giving zein alone at $3 \mathrm{~h}$. The systemic lysine concentration was particularly high at $\mathrm{I} h$ after the meal of supplemented zein. The portal PAA concentrations reflected more directly the absorption of amino acids from the small intestine and, despite the small increases, it was evident that the absorption peaks of the amino acids derived from the digestion of the protein 
occurred between $\mathrm{I}$ and $\mathbf{2} \mathrm{h}$ after ingestion. Although the precise position of the lysine peak after supplemented zein was given cannot be determined from the results, in order to account for the rapid disappearance of lysine from the gut and its absence from the plasma at later sampling times, it must be assumed that the peak of absorption occurred before $I h$. The concentrations of the free amino acids in the systemic blood represent a balance of processes such as absorption, catabolism and protein synthesis. The fall in the concentration of lysine after zein alone was given implied that the body pools of free amino acids supplied the lysine lacking in the diet for a short time, although they rapidly became depleted (cf. Longenecker \& Hause, 1958). From the evidence of the portal values, the rise in lysine concentration in systemic plasma at $3 \mathrm{~h}$ after ingestion was not associated with increased absorption from the intestine and was perhaps due to the mobilization of body proteins for energy, since there were concomitant rises in the concentrations of the other amino acids. Despite the fact that the concentration of lysine in blood plasma after ingestion of supplemented zein was at all times higher than that when zein alone was given, there was no detectable general fall in the PAA concentrations which might have indicated an immediate increase in tissue protein synthesis. The situation was the same when $\alpha$-protein and ADM-assay protein were supplemented with methionine, except that plasma valine concentrations were reduced, particularly in portal blood.

It can be seen from Fig. $\mathbf{x}$ that giving gluten alone resulted in peak PAA concentrations in both portal and systemic blood at about $\mathrm{I} h$ after ingestion. The somewhat later appearance of the lysine and particularly of the threonine peaks may have been due to a slower digestive release of these amino acids. It is possible that the slow absorption of threonine, perhaps due to slow digestion of threonine-containing peptides (Geiger, Courtney \& Geiger, I952; Erbersdobler, I969) rather than to a low availability in the protein, may contribute to its being the second limiting amino acid. De Muclenaere, Chen $\&$ Harper ( $1967 b$ ) observed that the threonine of maize gluten, although well absorbed from the digestive tract, was not fully utilized by rats.

When gluten supplemented with lysine and threonine was given, all the amino acids, including lysine and threonine, reached peak values in portal and systemic blood plasma at about $2 \mathrm{~h}$ after ingestion. Although threonine was added as a supplement, its level was lower in systemic plasma (although not in portal plasma except after $3 \mathrm{~h}$ ) than when gluten was given alone. As the second limiting acid, it is likely that its utilization was improved when lysine, the first limiting amino acid, was also added as a supplement, this factor overshadowing any rise due to the addition of threonine.

Longenecker \& Hause (1958) gave dogs gluten alone and found that peak plasma values of lysine, threonine and tryptophan occurred at $\mathrm{I}, 3$ and $4 \mathrm{~h}$ respectively after ingestion, whereas when gluten was given with lysine the peaks were at 3,2 and $3 \mathrm{~h}$. It is possible that the free amino acids added as supplements were absorbed more rapidly than those derived from the protein, but the net effect in both sets of experiments was to make the postprandial changes in plasma concentration of these amino acids, formerly limiting, similar to those of the other amino acids.

The present results with gluten showed evidence, in the shape of marked falls in almost all the PAA concentrations, of a rapid improvement in utilization of the protein 
as a result of supplementing it with lysine and threonine. The shift of the peak PAA concentrations in the plasma from $\mathrm{I}$ to $2 \mathrm{~h}$ may also be attributed to this enhanced synthesis of tissue protein: the increased removal of amino acids would delay the appearance of the peaks. Giving gluten alone resulted in high concentrations of soluble protein in the stomach, a composition of the soluble digesta consistent with a rapidly hydrolysed protein, and large, rapid increases in PAA concentrations. Thus the amino acids deriving from the digestion of gluten were rapidly absorbed at a rate sufficiently similar to that of the free amino acids to promote the efficient utilization observed when supplemented gluten was given.

In the experiments with other proteins we failed to demonstrate from the PAA concentrations any immediate enhancement of tissue protein synthesis as a result of adding supplements of free amino acids. This may have been due in part to the smaller rises in plasma concentrations when these less-rapidly digested proteins were given, but it is also possible that the observed differences in the rate of absorption of the free amino acids resulted in a less-efficient promotion of increased synthetic activity as a result of adding the supplements. Although it is improbable that the added supplements failed to enhance the nutritive value of the protein, it is possible that optimum performance is not readily obtained, particularly with less-soluble proteins. Several results by other groups of workers support this suggestion. Hogan, Gillespie, Koçtürk, O'Dell \& Flynn (r955) found that a diet containing maize protein supplemented with lysine and tryptophan produced growth inferior to that on a diet containing casein, even though the latter was not superior in amino acid content. De Muelenaere, Chen $\&$ Harper ( $1967 a$ ) and O. P. Walz (unpublished) have shown that rats subsisting on a diet in which lysine is limiting are more responsive to lysine added in an intact protein than in the free form, and Carpenter, March, Milner \& Campbell (x963), when conducting lysine assays with chicks, found that some biological values for available lysine were in excess of the chemical fluorodinitrobenzene values. These observations are readily explainable on the grounds that the rate of absorption of free lysine is different from that of lysine in an intact protein and the former is utilized less efficiently. Some workers have found that, similarly, protein hydrolysates were absorbed more rapidly than intact proteins (e.g. Zimmermann-Nielsen \& Schønheyder, I962; Scharrer \& Zucker, 1968), whereas others (Gupta et al. 1958; Crane \& Neuberger, I960) concluded that the ingestion of proteins or hydrolysates resulted in similar rates of $\mathrm{N}$ absorption, perhaps because they gave small meals of rapidly digested protein.

Thus the findings from the present work indicate that the degree of success of supplementing with free amino acids depends on more than the addition of correct quantities of the supplement. The simultaneity of appearance of amino acids from the supplement and from digestion of the protein is affected by the protein given, the size and frequency of the meals, and the presence and proportions of non-protein components in the meal. Although evidence of improved protein utilization upon addition of free amino acid supplements was obtained from changes in PAA concentrations when gluten was given, it does not appear possible to use PAA concentrations as a general indicator of the success of such supplements. 
We are grateful to Mr J. E. Cockburn and Mr A.P. Williams for carrying out amino acid analyses, and to Mrs A. Farmer, Mrs M. Payne and Miss S. Levin for technical assistance. Thanks are also due to Miss M. Tyler for care of the rats and to Dr J. E. Ford for helpful comments.

\section{REFERENCES}

Berg, C. P. \& Rose, W. C. (1929). F. biol. Chem. 82, 479.

Buraczewski, S., Porter, J. W. G., Rolls, B. A. \& Zebrowska, T. (1971). Br. F. Nutr. 25, 299.

Carpenter, K. J., March, B. E., Milner, C. K. \& Campbell, R. C. (1963). Br. F. Nutr. 17, 309.

Crane, C. W. \& Neuberger, A. (1960). Biochem. F. 74, 3 I3.

De Muelenaere, H. J. H., Chen, M.-L. \& Harper, A. E. (I967a). F. agric. Fd Chem. 15, 310.

De Muelenaere, H. J. H., Chen, M.-L. \& Harper, A. E. (r967b). F. agric. Fd Chem. 15, 3 I 8.

Erbersdobler, H. (1969). Z. Tierphysiol. Tierernälır. Futtermittelk. 25, I I 9.

Geiger, E. (1 947). F. Nutr. 34, 97.

Geiger, E. (r951). Fedn Proc. Fedn Am. Socs exp. Biol. 1o, 670.

Geiger, E., Courtney, G. W. \& Geiger, L. E. (1952). Archs Biochem. Biophys. 4r, 74.

Gupta, J. D., Dakroury, A. M. \& Harper, A. E. (1958). F. Nutr. 64, 447.

Hogan, A. G., Gillespie, G. T., Koçtürk, O., O'Dell, B. L. \& Flynn, L. M. (I955). 7. Nutr. 57, 225.

Longenecker, J. B. \& Tause, N. L. (1958). Nature, Lond. 182, 1739.

Melnick, D., Oser, B. L. \& Weiss, S. (1946). Science, N.Y. roz, 326.

Rogers, Q. R., Spolter, P. D. \& Harper, A. E. (1962). Archs Biochem. Biophys. 97, 497.

Rolls, B. A., Williams, A. P. \& Porter, J. W. G. (I969). Proc. Nutr. Soc. 28, 69 A.

Scharrer, E. \& Zucker, H. ( 1968 ). Z. Tierphysiol. Tierernähr. Futtermittelk. 23, 32 r.

Zebrowska, T. (1968). Br. F. Nutr. 22, 483 .

Zimmermann-Nielsen, C. \& Schønheyder, F. (1962). Biochim. biophys. Acta 63, 201. 